\title{
Screening for differential methylation status in fetal myocardial tissue samples with ventricular septal defects by promoter methylation microarrays
}

\author{
CHUN ZHU ${ }^{3 *}$, ZHANG-BIN YU ${ }^{1 *}$, XIAO-HUI CHEN ${ }^{1}$, YA PAN $^{1}$, \\ XIAO-YUE DONG ${ }^{1}$, LING-MEI QIAN ${ }^{2}$ and SHU-PING HAN ${ }^{1}$ \\ ${ }^{1}$ Department of Pediatrics, Nanjing Maternal and Child Health Hospital of Nanjing Medical University, Nanjing 210004; \\ ${ }^{2}$ Department of Cardiology, The First Affiliated Hospital of Nanjing Medical University, \\ ${ }^{3}$ Institute of Pediatrics, Nanjing Medical University, Nanjing 210029, P.R. China
}

Received September 8,2010; Accepted November 29, 2010

DOI: $10.3892 / \mathrm{mmr} .2010 .407$

\begin{abstract}
To identify and provide a global assessment of DNA methylation in fetal ventricular septal defect (VSD), genomic DNA extracted from fetal myocardial tissue samples with VSD ( $\mathrm{n}=21)$ and from normal fetal myocardial tissue samples $(n=15)$ was analyzed for gene methylation using array-based technology. Furthermore, the KIAA0310, RAB43, SIVA1 and NDRG2 genes were randomly selected for validation analysis using methylation-specific PCR. Our results revealed that 70 and 85 genes were regulated by hypermethylation and hypomethylation, respectively, in VSD. Different clusters of genes were associated with functions including embryo development, signal transduction, cell apoptosis and cell proliferation. In conclusion, this study identified a set of candidate genes whose expression is regulated by DNA methylation in fetal VSD.
\end{abstract}

\section{Introduction}

Congenital heart disease (CHD) is the most common type of developmental defect, occurring in almost $1 \%$ of all neonates (1). Ventricular septal defect (VSD) is the most commonly recognized CHD (2). VSD may exist alone or as an integral part of complex CHD (3). VSD is a multifactorial complex

Correspondence to: Dr Shu-Ping Han, Department of Pediatrics, Nanjing Maternal and Child Health Hospital of Nanjing Medical University, Nanjing 210004, P.R. China

E-mail: shupinghan@njmu.edu.cn

Dr Ling-Mei Qian, Department of Cardiology, The First Affiliated Hospital of Nanjing Medical University, Nanjing 210029, P.R. China E-mail:1mqian@njmu.edu.cn

*Contributed equally

Key words: DNA methylation, hypermethylation, hypomethylation, ventricular septal defect disease, in which genetic and environmental factors play important roles. Despite the availability of several surgical techniques to treat VSD, the exact molecular mechanism of this type of CHD remains unclear.

DNA methylation has been widely recognized as a potent mechanism for silencing gene expression and maintaining genome stability (4). DNA methylation is the predominant epigenetic alteration occurring in mammalian genomes, and plays a critical functional role in development, differentiation and disease (5). Previous studies have revealed that during embryonic development, the mammalian genome undergoes profound reprogramming of DNA methylation patterns in the germ and early pre-implantation embryos (6). Furthermore, the different prototypes of genes in each cell, tissue and organ are thought to be regulated by DNA methylation even during early development (7).

The recent advent of array-based techniques offers the opportunity for more comprehensive DNA methylation profiling (8). Comparing the DNA methylation profiles of myocardial tissue samples from VSD and normal fetuses, we provide novel information for identifying gene methylation that may be implicated in the pathological consequences of VSD.

\section{Materials and methods}

Tissue samples. Fetal myocardial tissue samples were obtained from Nanjing Maternal and Child Health Hospital. Myocardial tissue samples from $21 \mathrm{VSD}$ and 15 normal fetuses at 26 weeks of gestation were obtained during surgery for pregnancy termination owing to trauma of the pregnant women. All samples were collected with the approval of the appropriate institute ethics committee, and written consent was provided by each pregnant woman and her family. The speciments were immediately snap frozen in liquid nitrogen and then stored at $-80^{\circ} \mathrm{C}$ until analysis.

DNA methylation profiling by methylated DNA immunoprecipitation. The methylation profiling by methylated DNA immunoprecipitation (MeDIP) assay was performed using $3 \mathrm{mg}$ of sonicated genomic DNA (300-1,000 bp) and $10 \mathrm{mg}$ 
Table I. Primer sequences for amplifying the methylated (M) and unmethylated (U) genes

\begin{tabular}{|c|c|c|c|}
\hline Primers & Sequences $\left(5^{\prime}-3^{\prime}\right)$ & Product size (bp) & $\begin{array}{c}\text { Annealing } \\
\text { temperature }\left({ }^{\circ} \mathrm{C}\right)\end{array}$ \\
\hline
\end{tabular}

\begin{tabular}{|c|c|c|c|}
\hline KIAA0310 & $\begin{array}{l}\text { MF-GTTGATGTCGTAAGTCGGATAC } \\
\text { MR-ACCACCGCGATCCAACCTAAACAAC } \\
\text { UF-GTTGATGTTGTAAGTTGGATAT } \\
\text { UR-ACCACCACAATCCAACCTAAACAAC }\end{array}$ & 198 & 55 \\
\hline RAB43 & $\begin{array}{l}\text { MF-GTTTTTGATCGGCGGTTTGGGAGGT } \\
\text { MR-CGACTCTACCTTCAAACCCACCTCA } \\
\text { UF-GTTTTTGATTGGTGGTTTGGGAGGT } \\
\text { UR-CAACTCTACCTTCAAACCCACCTCA }\end{array}$ & 409 & 54 \\
\hline SIVA1 & $\begin{array}{l}\text { MF-AAATTAGATTCGTTTCGACGTC } \\
\text { MR-TCGATATACTAAACTCGACGCC } \\
\text { UF-TTTAAATTAGATTTGTTTTGATGTT } \\
\text { UR-TCAATATACTAAACTCAACACCACA }\end{array}$ & 321 & 55 \\
\hline NDRG2 & $\begin{array}{l}\text { MF-AGAGGTATTAGGATTTTGGGTACG } \\
\text { MR-GCTAAAAAAACGAAAATCTCGC } \\
\text { UF-AGAGGTATTAGGATTTTGGGTATGA } \\
\text { UR-CCACTAAAAAAACAAAAATCTCACC }\end{array}$ & 125 & 55 \\
\hline
\end{tabular}

of antibody against 5-methylcytidine (BI-MECY-1000; Eurogentec) as previously described (9). For PCR, $20 \mathrm{ng}$ of sonicated genomic input DNA and 1/40 of an MeDIP reaction were used. In each array, seven unamplified MeDIP reactions were pooled and hybridized together with sonicated genomic input DNA. Final promoter methylation $\log _{2}$ ratios of bound over input signals represent the average of three independent experiments, including one dye swap.

Methylation-specific PCR (MSP). Four differentially regulated genes identified with promoter methylation microarray analysis were randomly selected for validation analysis by MSP. DNA methylation patterns in the $\mathrm{CpG}$ islands of the KIAA0310, RAB43, SIVA1 and NDRG2 genes were determined by chemical treatment with sodium bisulfite and subsequent MSP, according to a previously described method (10). Primer sequences of these genes are described in Table I. Primers were purchased from Invitrogen (USA). Myocardial tissue DNA samples, either original or methylated in vitro by excess CpG (Sss.I) methyltransferase (NEB, USA), were used as positive controls for unmethylated and methylated DNA, respectively. Distilled water was used as a negative control.

Statistical analysis. Statistical analysis was performed using the $\chi^{2}$ test or Fisher's exact test and the Student's t-test if the data followed a normal distribution. A P-value of $<0.05$ (two-sided) was regarded as statistically significant. All data were analyzed with SPSS 13.0 for Windows.

\section{Results}

Methylation profiles of fetal ventricular tissue. A promoter methylation microarray was used to evaluate 21 ventricular tissues samples from VSD fetuses and 15 samples from normal healthy controls. The array identified 70 and 85 candidate

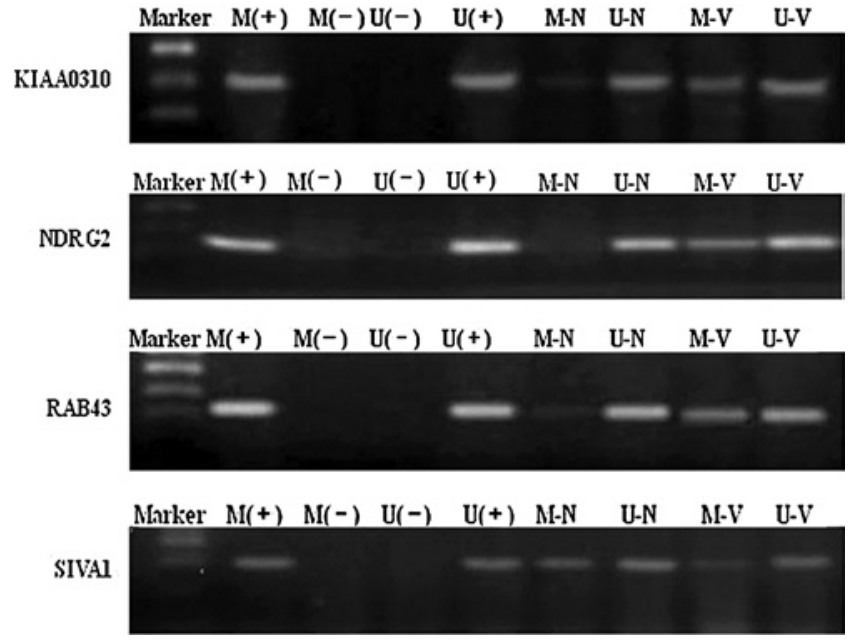

Figure 1. Representative results of methylation-specific PCR analyses of myocardial DNA samples from normal and VSD fetuses. The PCR products in lanes $\mathrm{M}$ and $\mathrm{U}$ reveal the presence of methylated and unmethylated templates, respectively, of the NOX5 gene. Lanes N and V contain the control and VSD templates, respectively. Marker, 100-bp DNA ladder; M(+), methylated positive control; $\mathrm{U}(+)$, unmethylated positive control; $\mathrm{M}(-)$ and $\mathrm{U}(-)$, negative controls.

genes regulated by hypermethylation and hypomethylation, respectively, in VSD (Table II).

Validation of the microarray results by MSP. To further evaluate and validate the results obtained by the microarrays, MSP analysis was performed in four randomly selected differentially expressed genes. Both hypermethylation and hypomethylation genes were selected in the ventricular tissues of the VSD fetuses for subsequent MSP analysis. Representative gel images of these four genes are shown in Fig. 1. Overall, the hypermethylation rate of $R A B 43, N D R G 2$ 
Table II. Promoter methylation in VSD genome.

\begin{tabular}{|c|c|c|}
\hline Chromosome & Gene & Description \\
\hline \multicolumn{3}{|c|}{ Hypermethylation } \\
\hline \multirow[t]{5}{*}{1} & GBP2 & Guanylate binding protein 2 , interferon-inducible \\
\hline & GJB4 & Gap junction protein, $\beta 4$ (connexin 30.3 ) \\
\hline & POGZ & Pogo transposable element with ZNF domain \\
\hline & OPN3 & Opsin 3 \\
\hline & RHOC & Ras homolog gene family, member $\mathrm{C}$ \\
\hline \multirow[t]{4}{*}{2} & SUSD4 & Sushi domain containing 4 \\
\hline & CYBRD1 & Cytochrome b reductase 1 \\
\hline & GPR148 & G protein-coupled receptor 148 \\
\hline & RPE & Ribulose-5-phosphate-3-epimerase \\
\hline \multirow[t]{3}{*}{3} & RAB43 & Member RAS oncogene family \\
\hline & MFN1 & Mitofusin 1 \\
\hline & KPNA1 & Karyopherin $\alpha 1$ (importin $\alpha 5$ ) \\
\hline \multirow[t]{2}{*}{4} & DRD5 & Dopamine receptor D5 \\
\hline & ANKRD17 & Ankyrin repeat domain 17 \\
\hline 5 & KIAA1191 & Kiaa1191 \\
\hline \multirow[t]{3}{*}{6} & MLLT4 & $\begin{array}{l}\text { Myeloid/lymphoid or mixed-lineage leukemia } \\
\text { (trithorax homolog, Drosophila) \%3B translocated to, } 4\end{array}$ \\
\hline & SSR1 & Signal sequence receptor, $\alpha$ \\
\hline & TMEM14C & Transmembrane protein $14 \mathrm{C}$ \\
\hline \multirow[t]{7}{*}{7} & HIST1H3F & Histone $1, \mathrm{H} 3 \mathrm{f}$ \\
\hline & RNF32 & Ring finger protein 32 \\
\hline & BCDIN3 & Bin3, bicoid-interacting 3, homolog (Drosophila) \\
\hline & RELN & Reelin \\
\hline & ZYX & Zyxin \\
\hline & C7orf20 & Chromosome 7 open reading frame 20 \\
\hline & FASTK & Fas-activated serine/threonine kinase \\
\hline \multirow[t]{3}{*}{8} & ANGPT2 & Angiopoietin 2 \\
\hline & FNTA & Farnesyltransferase, CAAX box, $\alpha$ \\
\hline & PTDSS 1 & Phosphatidylserine synthase 1 \\
\hline \multirow[t]{2}{*}{9} & KIAA0310 & Kiaa0310 \\
\hline & STOML2 & Stomatin (EPB72)-like 2 \\
\hline \multirow[t]{4}{*}{10} & DYDC1 & DPY30 domain containing 1 \\
\hline & LOC653471 & Similar to Ribosome biogenesis protein BMS1 homolog \\
\hline & FGF8 & Fibroblast growth factor 8 (androgen-induced) \\
\hline & ABI1 & Abl-interactor 1 \\
\hline \multirow[t]{5}{*}{11} & CHID1 & Chitinase domain containing 1 \\
\hline & EEF1G & Eukaryotic translation elongation factor $1 \gamma$ \\
\hline & MUCDHL & Mucin and cadherin-like \\
\hline & DKK3 & Dickkopf homolog 3 (Xenopus laevis) \\
\hline & LDHB & Lactate dehydrogenase $\mathrm{B}$ \\
\hline 12 & CLEC4C & C-type lectin domain family 4 , member $\mathrm{C}$ \\
\hline \multirow[t]{2}{*}{13} & THSD1 & Thrombospondin, type I, domain containing 1 \\
\hline & EBPL & Emopamil binding protein-like \\
\hline \multirow[t]{3}{*}{14} & WDR20 & WD repeat domain 20 \\
\hline & TRAPPC6B & Trafficking protein particle complex 6B \\
\hline & NDRG2 & NDRG family member 2 \\
\hline \multirow[t]{3}{*}{15} & NOX5 & NADPH oxidase, EF-hand calcium binding domain 5 \\
\hline & SNRPN & Small nuclear ribonucleoprotein polypeptide N \\
\hline & CLUAP1 & Clusterin associated protein 1 \\
\hline \multirow[t]{2}{*}{16} & CMTM1 & CKLF-like MARVEL transmembrane domain containing 1 \\
\hline & STUB1 & STIP1 homology and U-box containing protein 1 \\
\hline
\end{tabular}


Table II. Continued.

\begin{tabular}{|c|c|c|}
\hline Chromosome & Gene & Description \\
\hline 17 & $\begin{array}{l}\text { USP6 } \\
\text { SHMT1 } \\
\text { NT5C }\end{array}$ & $\begin{array}{l}\text { Ubiquitin specific peptidase } 6 \text { (Tre-2 oncogene) } \\
\text { Serine hydroxymethyltransferase } 1 \text { (soluble) } \\
\text { 5', 3'-nucleotidase, cytosolic }\end{array}$ \\
\hline 18 & $\begin{array}{l}\text { MBD1 } \\
\text { CXXC1 } \\
\text { PPP4R1 } \\
\text { RPL17 }\end{array}$ & $\begin{array}{l}\text { Methyl-CpG binding domain protein } 1 \\
\text { CXXC finger } 1 \text { (PHD domain) } \\
\text { Protein phosphatase } 4 \text {, regulatory subunit } 1 \\
\text { Ribosomal protein L17 }\end{array}$ \\
\hline 19 & $\begin{array}{l}\text { PRKACA } \\
\text { NFIX }\end{array}$ & $\begin{array}{l}\text { Protein kinase, cAMP-dependent, catalytic, } \alpha \\
\text { Nuclear factor I/X (CCAAT-binding transcription factor) }\end{array}$ \\
\hline 20 & $\begin{array}{l}\text { RAE1 } \\
\text { GGTLA4 }\end{array}$ & $\begin{array}{l}\text { RNA export } 1 \text { homolog }(\mathrm{S} . \text { pombe }) \\
\gamma \text {-glutamyltransferase-like activity } 4\end{array}$ \\
\hline 21 & $\begin{array}{l}\text { LOC284821 } \\
\text { CCT8 } \\
\text { U2AF1 } \\
\text { TRPM2 }\end{array}$ & $\begin{array}{l}\text { Similar to ribosomal protein L13a } \\
\text { Chaperonin containing TCP1, subunit } 8(\theta) \\
\text { U2 small nuclear RNA auxiliary factor } 1 \\
\text { Transient receptor potential cation channel, } \\
\text { Subfamily M, member } 2\end{array}$ \\
\hline 22 & $\begin{array}{l}\text { ZNF74 } \\
\text { PES1 }\end{array}$ & $\begin{array}{l}\text { Zinc finger protein } 74 \text { (Cos } 52) \\
\text { Pescadillo homolog } 1 \text {, containing BRCT domain } \\
\text { (zebrafish) }\end{array}$ \\
\hline$X$ & $\begin{array}{l}\text { SOX3 } \\
\text { ARSD } \\
\text { FAM39A }\end{array}$ & $\begin{array}{l}\text { SRY (sex determining region Y)-box } 3 \\
\text { Arylsulfatase D } \\
\text { Family with sequence similarity } 39 \text {, member A }\end{array}$ \\
\hline $\begin{array}{l}\text { Hypomethylati } \\
1\end{array}$ & $\begin{array}{l}\text { CDC20 } \\
\text { DAP3 } \\
\text { EXOSC10 } \\
\text { AGL }\end{array}$ & $\begin{array}{l}\text { Cell division cycle } 20 \text { homolog (S. cerevisiae) } \\
\text { Death associated protein } 3 \\
\text { Exosome component } 10 \\
\text { Amylo-1 }\end{array}$ \\
\hline 2 & $\begin{array}{l}\text { FLJ13305 } \\
\text { EEF1B2 }\end{array}$ & $\begin{array}{l}\text { Hypothetical protein FLJ13305 } \\
\text { Eukaryotic translation elongation factor } 1 \beta 2\end{array}$ \\
\hline 3 & $\begin{array}{l}\text { TP73L } \\
\text { ECT2 } \\
\text { RARB } \\
\text { EIF4A2 } \\
\text { NR1I2 } \\
\text { MME } \\
\text { ZNF9 } \\
\text { TATDN2 } \\
\text { HYAL1 } \\
\text { PPARG }\end{array}$ & $\begin{array}{l}\text { Tumor protein p73-like } \\
\text { Epithelial cell transforming sequence } 2 \text { oncogene } \\
\text { Retinoic acid receptor, } \beta \\
\text { Eukaryotic translation initiation factor } 4 \mathrm{~A} \text {, isoform } 2 \\
\text { Nuclear receptor subfamily } 1 \text {, group I, member } 2 \\
\text { Membrane metallo-endopeptidase } \\
\text { Zinc finger protein } 9 \\
\text { TatD DNase domain containing } 2 \\
\text { Hyaluronoglucosaminidase } 1 \\
\text { Peroxisome proliferative activated receptor, } \gamma\end{array}$ \\
\hline 4 & $\begin{array}{l}\text { PIGG } \\
\text { PDLIM5 }\end{array}$ & $\begin{array}{l}\text { Phosphatidylinositol glycan, class G } \\
\text { PDZ and LIM domain } 5\end{array}$ \\
\hline 5 & $\begin{array}{l}\text { RAD17 } \\
\text { TAF9 } \\
\text { BNIP1 } \\
\text { RAD1 } \\
\text { CCNG1 } \\
\text { PART1 }\end{array}$ & $\begin{array}{l}\text { RAD17 homolog (S. pombe) } \\
\text { TAF9 RNA polymerase II, TATA box binding protein } \\
\text { (TBP)-associated factor, } 32 \mathrm{kDa} \\
\text { BCL2/adenovirus E1B } 19 \mathrm{kDa} \text { interacting protein } 1 \\
\text { RAD1 homolog (S. pombe) } \\
\text { Cyclin G1 } \\
\text { Prostate androgen-regulated transcript } 1\end{array}$ \\
\hline 6 & $\begin{array}{l}\text { PECI } \\
\text { MYB }\end{array}$ & $\begin{array}{l}\text { Peroxisomal D3, D2-enoyl-CoA isomerase } \\
\text { V-myb myeloblastosis viral oncogene homolog (avian) }\end{array}$ \\
\hline 7 & $\begin{array}{l}\text { CDKN1A } \\
\text { TSC22D4 }\end{array}$ & $\begin{array}{l}\text { Cyclin-dependent kinase inhibitor 1A (p21, Cip1) } \\
\text { TSC22 domain family, member } 4\end{array}$ \\
\hline
\end{tabular}


Table II. Continued.

\begin{tabular}{|c|c|c|}
\hline Chromosome & Gene & Description \\
\hline 8 & $\begin{array}{l}\text { ALKBH4 } \\
\text { TM2D2 } \\
\text { PDLIM2 } \\
\text { PABPC1 } \\
\text { ADAM32 } \\
\text { YWHAZ }\end{array}$ & $\begin{array}{l}\text { AlkB, alkylation repair homolog } 4 \\
\text { TM2 domain containing } 2 \\
\text { PDZ and LIM domain } 2 \text { (mystique) } \\
\text { Poly(A) binding protein, cytoplasmic } 1 \\
\text { ADAM metallopeptidase domain } 32 \\
\text { Tyrosine 3-monooxygenase/tryptophan 5-monooxygenase } \\
\text { activation protein, } \zeta \text { polypeptide }\end{array}$ \\
\hline 9 & $\begin{array}{l}\text { MAF1 } \\
\text { PPP2R4 } \\
\text { CRAT } \\
\text { ROD1 }\end{array}$ & $\begin{array}{l}\text { MAF1 homolog (S. cerevisiae) } \\
\text { Protein phosphatase 2A, regulatory subunit B' (PR 53) } \\
\text { Carnitine acetyltransferase } \\
\text { Regulator of differentiation } 1 \text { (S. pombe) }\end{array}$ \\
\hline 10 & $\begin{array}{l}\text { PITRM1 } \\
\text { MAPK8 } \\
\text { ITGB1 } \\
\text { CDC2 } \\
\text { FUT11 } \\
\text { HELLS }\end{array}$ & $\begin{array}{l}\text { Pitrilysin metallopeptidase } 1 \\
\text { Mitogen-activated protein kinase } 8 \\
\text { Integrin, } \beta 1 \\
\text { Cell division cycle } 2, \mathrm{G} 1 \text { to } \mathrm{S} \text { and } \mathrm{G} 2 \text { to } \mathrm{M} \\
\text { Fucosyltransferase } 11 \\
\text { Helicase, lymphoid-specific }\end{array}$ \\
\hline 11 & $\begin{array}{l}\text { RPS6KB2 } \\
\text { WT1 } \\
\text { CD44 } \\
\text { KIAA0652 }\end{array}$ & $\begin{array}{l}\text { Ribosomal protein } \mathrm{S} 6 \text { kinase, } 70 \mathrm{kDa} \text {, polypeptide } 2 \\
\text { Wilms tumor } 1 \\
\text { CD44 molecule (Indian blood group) } \\
\text { Kiaa0652 }\end{array}$ \\
\hline 12 & $\begin{array}{l}\text { PA2G4 } \\
\text { BCL2L14 }\end{array}$ & $\begin{array}{l}\text { Proliferation-associated 2G4, } 38 \mathrm{kDa} \\
\text { BCL2-like } 14 \text { (apoptosis facilitator) }\end{array}$ \\
\hline 13 & $\begin{array}{l}\text { HMGB1 } \\
\text { CDK8 }\end{array}$ & $\begin{array}{l}\text { High-mobility group box } 1 \\
\text { Cyclin-dependent kinase } 8\end{array}$ \\
\hline 14 & $\begin{array}{l}\text { SIVA1 } \\
\text { ATP6V1D } \\
\text { WDR20 }\end{array}$ & $\begin{array}{l}\text { CD27-binding(Siva) Protein } \\
\text { ATPase, } \mathrm{H}^{+} \text {transporting, lysosomal } 34 \mathrm{kDa}, \mathrm{V} 1 \text { subunit D } \\
\text { WD repeat domain } 20\end{array}$ \\
\hline 15 & $\begin{array}{l}\text { BMF } \\
\text { NUSAP1 }\end{array}$ & $\begin{array}{l}\text { Bcl } 2 \text { modifying factor } \\
\text { Nucleolar and spindle associated protein } 1\end{array}$ \\
\hline 16 & $\begin{array}{l}\text { CDK10 } \\
\text { ALDOA }\end{array}$ & $\begin{array}{l}\text { Cyclin-dependent kinase (CDC2-like) } 10 \\
\text { Aldolase A, fructose-bisphosphate }\end{array}$ \\
\hline 17 & $\begin{array}{l}\text { UBB } \\
\text { BIRC5 } \\
\text { CDK5RAP3 } \\
\text { MAPK7 } \\
\text { PRKAR1A }\end{array}$ & $\begin{array}{l}\text { Ubiquitin B } \\
\text { Baculoviral IAP repeat-containing } 5 \text { (survivin) } \\
\text { CDK5 regulatory subunit associated protein } 3 \\
\text { Mitogen-activated protein kinase } 7 \\
\text { Protein kinase, cAMP-dependent, regulatory, type I, } \alpha \\
\text { (tissue specific extinguisher } 1 \text { ) }\end{array}$ \\
\hline 18 & $\begin{array}{l}\text { NFATC1 } \\
\text { CDH7 }\end{array}$ & $\begin{array}{l}\text { Nuclear factor of activated T-cells, cytoplasmic, } \\
\text { calcineurin-dependent } 1 \\
\text { Cadherin } 7 \text {, type } 2\end{array}$ \\
\hline 19 & CAPNS1 & Calpain, small subunit 1 \\
\hline 20 & $\begin{array}{l}\text { TFAP2C } \\
\text { SNRPB2 } \\
\text { WFDC2 } \\
\text { GNAS } \\
\text { PRKCBP1 }\end{array}$ & $\begin{array}{l}\text { Transcription factor AP- } 2 \gamma \text { (activating enhancer } \\
\text { binding protein } 2 \gamma \text { ) } \\
\text { Small nuclear ribonucleoprotein polypeptide B" } \\
\text { WAP four-disulfide core domain } 2 \\
\text { GNAS complex locus } \\
\text { Protein kinase C binding protein } 1\end{array}$ \\
\hline 21 & $\begin{array}{l}\text { ATP5J } \\
\text { DSCR3 } \\
\text { SON }\end{array}$ & $\begin{array}{l}\text { ATP synthase, } \mathrm{H}^{+} \text {transporting, mitochondrial F0 complex, } \\
\text { subunit F6 } \\
\text { Down syndrome critical region gene } 3 \\
\text { SON DNA binding protein }\end{array}$ \\
\hline
\end{tabular}


Table II. Continued.

\begin{tabular}{|c|c|c|}
\hline Chr & Gene & Description \\
\hline \multirow[t]{6}{*}{22} & GNAZ & $\begin{array}{l}\text { Guanine nucleotide binding protein ( } \mathrm{G} \text { protein }) \text {, } \\
\alpha \mathrm{z} \text { polypeptide }\end{array}$ \\
\hline & PICK1 & Protein interacting with PRKCA 1 \\
\hline & SLC2A11 & $\begin{array}{l}\text { Solute carrier family } 2 \text { (facilitated glucose transporter), } \\
\text { Member } 11\end{array}$ \\
\hline & EIF3S7 & $\begin{array}{l}\text { Eukaryotic translation initiation factor } 3 \\
\text { Subunit } 7 \zeta, 66 / 67 \mathrm{kDa}\end{array}$ \\
\hline & SULT4A1 & Sulfotransferase family 4A, member 1 \\
\hline & PDGFB & $\begin{array}{l}\text { Platelet-derived growth factor beta polypeptide } \\
\text { [simian sarcoma viral (v-sis) oncogene homolog] }\end{array}$ \\
\hline \multirow[t]{4}{*}{$\mathrm{X}$} & RPL10 & Ribosomal protein L10 \\
\hline & FTSJ1 & FtsJ homolog 1 (E.coli) \\
\hline & NKAP & $\mathrm{NF}-\kappa \mathrm{B}$ activating protein \\
\hline & RPL10 & Ribosomal protein L10 \\
\hline
\end{tabular}

and KIAA0310 in VSD $(85.7 \%, 18 / 21 ; 76.2 \%, 16 / 21$ and $71.4 \%$, $15 / 21$; respectively) $(\mathrm{P}<0.05)$ was higher than that of the normal tissues. The hypomethylation rate of SIVA1 in VSD $(65.3 \%, 13 / 21)(\mathrm{P}<0.05)$ was higher than that of the normal tissues.

\section{Discussion}

Currently, pre-natal diagnosis of VSD is relatively difficult and surgical treatment of VSDs carries both mortality and morbidity risks, even though it is the most common open heart procedure performed in pediatric cardiac surgery $(11,12)$. The heart is the first organ to form during embryogenesis, and its development is controlled by a series of important genes (13). Epigenetic processes, including DNA methylation, are thought to control gene expression during the differentiation and development of cardiac tissues $(14,15)$. The relationship between DNA methylation and heart development is currently the focus of CHD studies.

In the present study, we utilized promoter methylation microarray technology to obtain an overall profile of the gene methylation of myocardial tissue in fetal VSD. Our analysis identified 70 and 85 genes regulated by hypermethylation and hypomethylation, respectively, in VSD. These genes are involved in embryo development, signal transduction, cell apoptosis and cell proliferation.

SSR1 and NDRG2 were found to be hypermethylation genes. SSR1 is a subunit of the translocon-associated protein (TRAP) complex (16). Human and mouse studies have revealed that SSR1 is maternally supplied until the eight-cell stage, and is then constitutively expressed during embryogenesis (17). Previous studies have suggested that SSR1 plays a crucial role in mammalian heart development and may be involved in the translocation of factors necessary for the maturation of endocardial cushions. For example, homozygous SSRI mutant pups die at birth, possibly as a result of severe cardiac defects (18). NDRG2 is one of the four members of the new NDRG (N-myc downstream-regulated gene) family (19-21).
Previously, the expression of NDRG2 mRNA was examined in mouse embryos and in adult human hearts $(22,23)$. During mouse development, NDRG2 protein expression was observed in the heart as early as E9.5, and was present at higher levels in the heart atria between E14.5 and E17.5 (24). In this study, we found that the proportion SSR1 and NDRG2 promoter hypermethylation was significantly higher in the VSD cases than in the controls. We speculate that the SSRI and NDRG2 genes may display silencing by aberrant methylation during cardiac morphogenesis and maturation in fetuses with VSD.

The endoplasmic reticulum (ER) is a multifunction organelle involved in the synthesis and packaging of proteins (25). ER functions are disturbed by various stress conditions (ER stress), including the inhibition of protein glycosylation, the reduction of disulfide bond formation, calcium depletion from the ER lumen and the impairment of protein transport from the ER to the Golgi (26). Several lines of evidence indicate that ER stress may be involved in the development of the embryonic heart. Mao et al (27) revealed that, during early heart organogenesis, Grp78 is activated through cooperation between cell type-specific transcription factors and endoplasmic reticulum stress response element (ERSE)-binding factors. In this study, we screened and identified the promoter hypermethylation of the RAB43 and KIAA0310 genes in VSD tissues. Previous studies have found that overexpression and, to a lesser extent, small interfering RNA depletion of KIAA0310 inhibit ER-to-Golgi transport (28). RAB43 has also been observed to play a role in anterograde trafficking of cargo from the ER to the Golgi (29). Therefore, we propose that the hypermethylation of RAB43 and KIAA0310 leads to ER-to-Golgi transport dysfunction, which further leads to the occurrence of ER stress. ER stress is thought to contribute to the development of the abnormal embryonic heart, including VSD.

DNA hypomethylation is linked to genetic instability characterized by chromosomal aberration and elevated mutation rates (30), and may lead to the loss or silencing of gene function $(31,32)$. In this study, we evaluated the 
promoter hypomethylation of 85 genes in VSD. Among the genes examined, the apoptosis-related genes SIVAI and MDM2 showed hypomethylation in the VSD, but not in the control, samples. Hypomethylation is a crucial step in the transformation of the endocardial cushion to ventricular septum in the development of the embryonic four-chambered heart. The development of the form and structure of the endocardial cushion is accompanied by precise patterns of abundant cell death, which has the morphological features of programmed cell death (apoptosis) (33). Hypomethylation of SIVA1 and MDM2 may lead to the the loss of mitotic function, which regulates mitotic balance in tissue renewal.

In conclusion, we used methylation profiling to identify a set of candidate genes whose expression is regulated by DNA methylation in VSD. The methylation profiling also identified additional candidate genes for future investigation.

\section{Acknowledgements}

This study was supported by a grant from the National Natural Science Foundation of China (nos. 30973213 and 81070138).

\section{References}

1. Hoffman JI and Kaplan S: The incidence of congenital heart disease. J Am Coll Cardiol 39: 1890-1900, 2002.

2. Came E, Stoll M and Clementi M: Evaluation of prenatal diagnosis of congenital heart diseases by ultrasound: experience from 20 European registries. Ultrasound Obstet Gynecol 17: 385-391, 2001.

3. Dan-Dan W, Xiao-Peng D, Wei C and Hui L: The value of spatiotemporal image correlation technique in the diagnosis of fetal ventricular septal defect. Arch Gynecol Obstet: May, 2010 (E-pub ahead of print).

4. Robertson KD: DNA methylation and human disease. Nat Rev Genet 6: 597-610, 2005.

5. Bird A: DNA methylation patterns and epigenetic memory. Gene Dev 16: 6-21, 2002.

6. Reik W, Dean W and Walter J: Epigenetic reprogramming in mammalian development. Science 293: 1089-1093, 2001.

7. Kim KC, Friso S and Choi SW: DNA methylation, an epigenetic mechanism connecting folate to healthy embryonic development and aging. J Nutr Biochem 20: 917-926, 2009.

8. Richter J, Ammerpohl O, Martín-Subero JI, MontesinosRongen M, Bibikova M, Wickham-Garcia E, Wiestler OD, Deckert $M$ and Siebert R: Array-based DNA methylation profiling of primary lymphomas of the central nervous system. BMC Cancer 9: 455, 2009.

9. Weber M, Hellmann I, Stadler MB, Ramos L, Pääbo S, Rebhan M and Schübeler D: Distribution, silencing potential and evolutionary impact of promoter DNA methylation in the human genome. Nat Genet 39: 457-466, 2007.

10. Herman JG, Graff JR, Myohanen S, Nelkin BD and Baylin SB: Methylation-specific PCR: a novel PCR assay for methylation status of CpG islands. Proc Natl Acad Sci USA 93: 9821-9826, 1996.

11. Paladini D, Palmieri S, Lamberti A, Teodoro A, Martinelli P and Nappi C: Characterization and natural history of ventricular septal defects in the fetus. Ultrasound Obstet Gynecol 16: $118-122,2000$.

12. Nygren A, Sunnegårdh J and Berggren H: Preoperative evaluation and surgery in isolated ventricular septal defects: a 21 year perspective. Heart 83: 198-204, 2000.

13. Olson EN: Gene regulatory networks in the evolution and development of the heart. Science 313: 1922-1927, 2006.
14. Meyer K, Zhang H and Zhang L: Direct effect of cocaine on epigenetic regulation of PKCepsilon gene repression in the fetal rat heart. J Mol Cell Cardiol 47: 504-511, 2009.

15. Gibney ER and Nolan CM: Epigenetics and gene expression. Heredity 105: 4-13, 2010.

16. Nagasawa K, Higashi T, Hosokawa N, Kaufman RJ and Nagata K: Simultaneous induction of the four subunits of the TRAP complex by ER stress accelerates ER degradation. EMBO Rep 8: 483-489, 2007.

17. Hirama T, Miller CW and Koeffler HP: Translocon-associated protein alpha transcripts are induced by granulocyte-macrophage colonystimulating factor and exhibit complex alternative polyadenylation. FEBS Lett 455: 223-227, 1999.

18. Mesbah K, Camus A, Babinet C and Barra J: Mutation in the Trapalpha/Ssr1 gene, encoding translocon-associated protein alpha, results in outflow tract morphogenetic defects. Mol Cell Biol 26: 7760-7771, 2006.

19 Van Belzen N, Dinjens W, Diesveld MP, Groen NA, van der Made AC, Nozawa Y, Vlietstra R, Trapman J and Bosman FT: A novelgene which is up-regulated during colon epithelial cell differentiation and down-regulated in colorectal neoplasms. Lab Invest 77: 85-92, 1997.

20. Zhao W, Tang R, Huang Y, Wang W, Zhou Z, Gu S, Dai J, Ying K, Xie Y and Mao Y: Cloning and expression pattern of the human NDRG3 gene. Biochim Biophys Acta 28: 134-138, 2001.

21. Ohki T, Hongo S, Nakada N, Maeda A and Takeda M: Inhibition of neurite outgrowth by reduced level of NDRG4 protein in antisense transfected PC12 cells. Brain Res Dev Brain Res 135: 55-63, 2002.

22. Okuda $\mathrm{T}$ and Kondoh H: Identification of new genes ndr2 and ndr3 which are related to Ndr1/RTP/Drg1 but show distinct tissue specificity and response to N-myc. Biochem Biophys Res Commun 266: 208-215, 1999.

23. Zhou RH, Kokame K, Tsukamoto Y, Yutani C, Kato H and Miyata T: Characterization of the human NDRG gene family: a newly identified member, NDRG4, is specifically expressed in brain and heart. Genomics 73: 85-97, 2001.

24. Hu XL, Liu XP, Deng YC, Lin SX, Wu L, Zhang J, Wang LF, Wang XB, Li X, Shen L, Zhang YQ and Yao LB: Expression analysis of the NDRG2 gene in mouse embryonic and adult tissues. Cell Tissue Res 325: 67-76, 2006.

25. Anken E, Braakman I and Craig E: Versatility of the endoplasmic reticulum protein folding factory. Crit Rev Biochem Mol Biol 40: 191-228, 2005.

26. Oyadomari S, Araki E and Mori M: Endoplasmic reticulum stress-mediated apoptosis in pancreatic $\beta$-cells. Apoptosis 7: 335-345, 2002.

27. Mao C, Tai WC, Bai Y, Poizat $\mathrm{C}$ and Lee AS: In vivo regulation of Grp78/BiP transcription in the embryonic heart: role of the endoplasmic reticulum stress response element and GATA-4. J Biol Chem 281: 8877-8887, 2006.

28. Watson P, Townley AK, Koka P, Palmer KJ and Stephens DJ: Sec16 defines endoplasmic reticulum exit sites and is required for secretory cargo export in mammalian cells. Traffic 7: 1678-1687, 2006.

29. Dejgaard SY, Murshid A, Erman A, Kizilay O, Verbich D, Lodge R, Dejgaard K, Ly-Hartig TB, Pepperkok R, Simpson JC and Presley JF: Rab18 and Rab43 have key roles in ER-Golgi trafficking. J Cell Sci 121: 2768-2781, 2008.

30. Wilson AS, Power BE and Molloy PL: DNA hypomethylation and human diseases. Biochim Biophys Acta 1775: 138-185, 2007.

31. Cui H, Cruz-Correa M, Giardiello FM, Hutcheon DF, Kafonek DR, Brandenburg S, Wu Y, He X, Powe NR and Feinberg AP: Loss of IGF2 imprinting: a potential marker of colorectal cancer risk. Science 299: 1753-1755, 2003.

32. Jicai Z, Zongtao Y, Jun L, Haiping L, Jianmin W and Lihua H: Persistent infection of hepatitis B virus is involved in high rate of p16 methylation in hepatocellular carcinoma. Mol Carcinog 45: 530-536, 2006

33. Abdelwahid E, Pelliniemi LJ and Jokinen E: Cell death and differentiation in the development of the endocardial cushion of the embryonic heart. Microsc Res Tech 58: 395-403, 2002. 